\title{
A Preliminary Study of the Internet of Things Capabilities, Integration on Halal Food Supply Chain Performance and Sustainable Advantage
}

\author{
Fikry Karim ${ }^{1}$, Rudy Gosal ${ }^{2}$, Femilia Zahra ${ }^{1}$, Suryadi Hadi², Rahmat Fatahillah ${ }^{2}$ \\ ${ }^{1}$ Department of Accounting, Tadulako University, Palu-Indonesia \\ ${ }^{2}$ Department of Management, Tadulako University, Palu-Indonesia \\ *Corresponding Author: suryadihadi@ untad.ac.id
}

\begin{abstract}
The application of halal, especially in the supply chain, is one of the areas of research that requires further study. This study aims to identify the relationship between IoT and operational performance in halal supply chain applications. Literature search is carried out to support researchers in formulating models. Researchers use several data bases to search scientific journals, including Google Scholar and ResearchGate. Researchers obtained several articles related to research topics from several reputable journal groups. The results of the literature search that were carried out succeeded in formulating a research model for the effect of IoT on operational performance in HFSC. This study formulates a research model that can be recommended for further research in the future. This research is included in the conceptual category where this research model still requires empirical research to generalize the existence of the theory. The research model produced in this study is still under-researched in the realm of the halal food supply chain.
\end{abstract}

Keywords: IoT, integrasi, halal food supply chain, sustainable advantage

\section{INTRODUCTION}

Consumers more aware of halal food and it leads to pressure manufacturing process. The food industry is highly demanded by its consumers to be able to provide satisfaction in the form of halal assurance and the quality of the food they consume. Intelligent and dynamic production systems, as well as mass production of IR 4.0-compliant items [1]. It entails putting in place integrated digital elements that unify and govern physical equipment, sensors, ICT, and the Internet of Things (IoT) [2].Disturbances that can hinder production schedules and production rates can be identified early due to the use of remote production monitoring and sensors that assist in identifying and controlling product and operational conditions[3].

The development of local businesses in terms of increasing productivity, efficiency, quality and skills development can be realized. The visibility of food industry activities from upstream to downstream activities can be traced thanks to the technological advances of the industrial revolution. The Internet of Things, Big Data, Cloud Computing, and CyberPhysical Systems are all examples of how this industrial revolution is progressing. Previous studies have shown that manufacturing can reduce waste and increase efficiency due to the use of technology that enables data operations[4].

There are many obstacles faced in the use of technology, especially in developing countries. The overall lower technology intensity can hinder the realization of integrity. Limited capital investment can also be an issue that is always faced by entrepreneurs. In addition, the expertise of human resources which is a factor of production can be an obstacle in the application of technology in an industry [1]. As a result, from upstream to downstream, it is critical to integrate operations in the processing of raw materials into final goods. [5]. 
Supply chain management is a branch of science that discusses the management of business activities from upstream to downstream[6]. Collaboration and integration between activities is a vital part in maintaining the harmony of any very complex activity[7]. In addition, the human factor of production becomes important in operating its role in the supply chain[8]. Human resource expertise will have a significant effect on supply chain performance[9]. The role of information technology in this case the internet is also a medium to support all supply chain activities[10].

The Internet of Things (IoT) plays a very important role in the current digital industry era in various sectors[3]. The Internet is very helpful in integrating activities within the corporate structure. Internet of Things (IoT) can play a role in increasing the level of business operational efficiency. However, the role of IoT in the area of the halal food industry is still lacking, so studies on the role of IoT need to be studied further. This paper is expected to increase the number of studies on the role of IoT in the halal food industry which is still lacking.

This research will look at the relationship between IoT capabilities and supply chain integration in increasing supply chain performance in the halal industry sector, as well as learn more about the findings of previous academic studies and propose research concepts. In the future, empirical research will be conducted.

\section{LITERATURE REVIEW}

\subsection{Halal Food Supply Chain (HFSC)}

From the standpoint of the manufacturing process, using technologies like remote monitoring and control and sensors to monitor production and control of products and operating conditions can identify potential problems that could disrupt production schedules and have a negative impact on production levels. It's identical to how ICT is used in the production process: it reduces troubleshooting time as activities shift from reactive to preventive. It is the simplest approach to manage and provide the fork farm's halal supply chain from production to consumer.

\subsection{IoT Capabilities and Supply Chain Integration}

In opposition to the well-established ties between manufacturers, suppliers, and customers, supply chain integration (SCI) is a relatively new concept. In the literature, however, this collaborative interaction is revealed to be one-dimensional [11],[12].
Furthermore, a number of studies were conducted on the dynamic relationship that exists between supply chain partners. [13]. In addition, Some research considers the supply chain to be a single system, whereas others break it down into subsystems [14]. Material and part flow from one supply chain component to the next is described by SCI. [7]. The flow of money, resources, and information within a supply chain subsystem, according to some authors, is referred to as SCI. Previous research, however, has overlooked the essence of the SCI technique.

\subsection{Supplier Integration and Halal Food Supply Chain}

Structures, designs, procedures, and tactics can all be influenced by the external environment, according to structural contingency theory. The external environment in manufacturing includes suppliers and customers. To achieve operational and organizational performance in supply chains, manufacturers must design, choose, and implement strategies for their internal and external environments. [15]. The organization's internal and external environment must be responded to through organizational strategy in order for the organization to perform well.[14].

Stronger customer-manufacturer ties not only keep customers loyal to them, but they also allow firms to better understand their customers' demands. Information is shared. The manufacturer can estimate product design, production planning, production time, costs, inventory levels, and customer requirements. When manufacturers and customers have a good working relationship, they can share information. As a result, customer integration (CI) can assist manufacturers in becoming more customer-centric through collaboration and information exchange in order to improve operational, supply chain, and organizational performance.[16].

By allowing firms to harness intelligence in collaborative processes, customer integration (CI) often enables them to understand customers, generate higher value for customers, lower costs, and recognize rapid changes in customer demand, market turmoil, and competition strategy. As a view customer is involved in the planning, product creation, and delivery process, and as a manufacturer receives information and feedback directly from its customers, CI can boost customer satisfaction. In addition, buyers indirectly contribute in product invention and development.[17]. 
Supplier-manufacturer integration can lead to strategic collaboration between suppliers and manufacturers. Suppliers can use SI to anticipate and comprehend their producers' needs, as well as foresee quick changes in producer demand. SI encourages manufacturers and suppliers to share information, learn about each other's capabilities, plan production, and define product delivery methods, timelines, and costs. As a result, IS plays a critical role in operational performance through planning, production, delivery, and service.[16].

\section{METHODOLOGY}

This paper was prepared using secondary data obtained from literature reviews from a few scholars who have published articles, journals and documents. Researchers conducted searches on several pages including Google Scholar, ResearchGate and other pages. Several papers, journals and documents can be obtained and compiled to support the conceptual framework. The keywords used in this search include: "IoT", "Customer Integration", "Internal Integration", "Supplier Integration", "Operational Performance", "Halal Food Supply Chain Performance". This paper does not perform a confirmatory test of the conceptual framework by testing hypotheses because this paper is categorized as a conceptual study.

\section{PROPOSED CONCEPTUAL FRAMEWORK}

Technological sophistication is not only associated with sophistication and its application, but is also associated with other dimensions, namely social, psychological, economic, and environmental. The development of the role of IoT is increasingly important because it can be easily reached widely in the context of business operations.

According to Wilson [18], Working knowledge of halal and the ability to develop information sharing, collaboration, and collaboration networks are more vital than a large and rising halal market, according to - Halal (particularly for food) is a farm-to-table concept that requires nutritious foods to be prepared in a clean and hygienic manner from authorized components. [19] as well as in accordance with Islamic law. Halal is a holistic notion that focuses on both physical qualities and moral sense across the production chain from an Islamic perspective. [20]. It is important for Muslim customers to choose halal products.

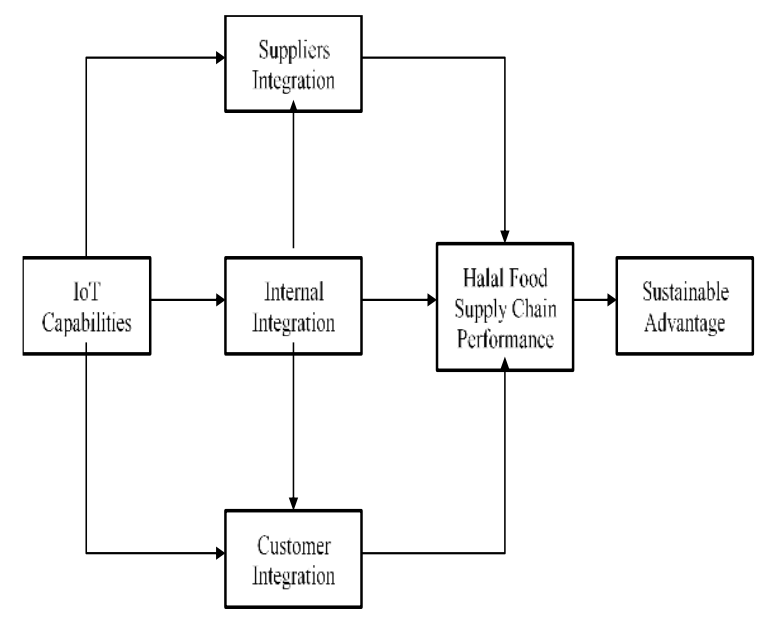

Figure 1 Conceptual Framework

The market for halal items is rising as well. By 2020, the worldwide halal market is estimated to reach USD 2.6 trillion. Control and regulate the flow of resources, information, and capital through stakeholder cooperation and collaboration, generating value to boost supply and extending Halal and Toyyib beyond the reach of the fork. [21]. The aims of halal supply chain management include product diversity, product quality, international suppliers, established business ties, and protocols between suppliers, manufacturers, distributors, retailers, and customers.

Internal integration with manufacturers and external integration with suppliers and customers are the two dimensions of SCI. External integration, on the other hand, can be done in both directions.[22]. Integration can be utilized as a strategic strategy inside the supply chain to engage with other supply chain partners and ensure a seamless flow of information and resources across inter-organizational and intraorganizational operations. SCI strives to enhance the flow of information, resources, money, products, and services in order to better serve customers, which will result in speedier organizational processes and cheaper operational costs [23]. SCI promotes strategic collaboration among supply chain partners. This has the potential to be both operational and strategic.[24]. SCI also rewards supply chain partners for sharing information, shortening delivery times, and establishing trust over time [25]. Because customer satisfaction is the primary goal of SCI, it emphasizes the importance of inter- and intra-organizational processes and their outcomes for operational and organizational success. 
External integration mainly refers to customer and supplier integration. Both CI and SI can help firms establish strategies, processes, practices, and collaboration through fostering strategic partnerships between manufacturers, suppliers, and customers. [26]. CI involves competence,
Because IS is so tightly linked to product design, manufacturing, and performance, it not only improves the connection between manufacturers and suppliers, but it also improves customer satisfaction, service, and loyalty. [29]. Moreover, IS can improve communication between suppliers and manufacturers to improve operational and organizational

Table 1. Proposed Variables and Indicators

\begin{tabular}{|c|c|c|c|}
\hline Variable & Indicator & Variable & Indicator \\
\hline IOT Capability & $\begin{array}{l}\text { - Level identification } \\
\text { - } \text { Track and trace } \\
\text { - } \text { Control supply chain } \\
\text { - } \text { Autonomous decisions } \\
\text { - } \text { Real-time information } \\
\text { - } \text { Tactical decision } \\
\text { - Strategic decision } \\
\text { - Intra organizational } \\
\text { information sharing }\end{array}$ & Customer Integration & $\begin{array}{l}\text { - Stength of linkage } \\
\text { - Regular contact } \\
\text { - Customer experience } \\
\text { - Accurate plan } \\
\text { - Checkout process } \\
\text { - Simplify the payment } \\
\text { receivable }\end{array}$ \\
\hline Supplier Integration & $\begin{array}{l}\text { - Exchange information } \\
\text { - Inventory order } \\
\text { - Procurement } \\
\text { - Real-time demand } \\
\text { - forecasts } \\
\text { - Strategic partnerships } \\
\text { - Improve process } \\
\text { - Account payable process } \\
\text { - Logistics process } \\
\text { - Receiving process }\end{array}$ & Halal Food Supply Chain & $\begin{array}{l}\text { - Flexibility } \\
\text { - Cycle time } \\
\text { - Total supply chain } \\
\text { management } \\
\text { - Cost of good sold } \\
\text { - Value-added } \\
\text { productivity }\end{array}$ \\
\hline Internal Integration & $\begin{array}{l}\text { - } \text { Real-time communication } \\
\text { - } \text { Collaboration across } \\
\text { functional } \\
\text { - } \text { Real-time inventory levels } \\
\text { - } \text { Real-time logistics } \\
\text { process } \\
\text { - Cross functional teams } \\
\text { - Stockouts } \\
\text { - Reflenishment }\end{array}$ & Sustainable Advantage & $\begin{array}{l}\text { - Sales volume } \\
\text { - Quality } \\
\text { - Delivered on time } \\
\text { - Production costs } \\
\text { - Profit }\end{array}$ \\
\hline
\end{tabular}

practice, and critical customer coordination, whereas IS is concerned with competence, practice, and integration with important suppliers [27]. Customers and suppliers can both connect with CI and SI, while manufacturers can efficiently interact and synchronize processes to satisfy their customers' needs. [28]. performance [26]. IS can also help improve operational and organizational performance by improving communication, exchanging information, connecting people, and planning, production capacity, and inventory management. As a result, integrating consumers and suppliers can help organizations 
enhance their operations, supply chains, and overall performance.[14], [16].

Based on the description of the literature review, this paper formulates several hypotheses as follows:

Preposition 1:

IoT Capabilities positively influence supplier integration

Preposition 2:

IoT Capabilities positively influence internal integration

Preposition 3:

IoT Capabilities positively influence customer integration

Preposition 4:

Supplier integration positively influences halal food supply chain

Preposition 5:

Internal integration positively influences halal food supply chain

Preposition 6:

Customer integration positively influence halal food supply chain

\section{CONCLUSION}

Optimizing the performance of Halal Food Supply Chain (HFSC) which was previously mediated by operational performance cannot be separated from the role of IoT which connects the internal activities of the focal company with its suppliers and customers. This study leads to a theoretical understanding of the role of IoT as a factor driving operational and business performance because it can integrate upstream and downstream activities from the halal food supply chain. The role of IoT can encourage all existing entities to make decisions based on the same facts and identify activities that do not meet halal standards, both upstream and downstream of the supply chain. The application of IoT will further tighten competition between business actors which will lead to improved services to consumers, especially in terms of halal assurance. This paper is included in the conceptual category so that in the future it must be proven by field research with large respondents and the research area is recommended in Muslim and non-Muslim countries. Subsequent research strongly supports the strengthening of theories related to the halal food supply chain (HFSC).

\section{AUTHORS' CONTRIBUTIONS}

RG conceived of this study and coordinated research activities. FK participated in the sequence alignment and drafted the manuscript. FZ participated in design the manuscript. SH participated in collecting and reviewed articles. RF participated in delivered questionnaires. All authors read and approved the final manuscript.

\section{ACKNOWLEDGMENTS}

This study was conducted under DANA DIPA 2021 Tadulako University.

\section{REFERENCES}

[1] A. A. Yudho Yudhoanto, "Pengantar Teknologi Internet of Things(IoT)," Yudho Yudhoanto, Abdul Aziz, 2019.

[2] P. Brous, M. Janssen, and P. Herder, "The dual effects of the Internet of Things (IoT): A systematic review of the benefits and risks of IoT adoption by organizations," International Journal of Information Management. 2020, doi: 10.1016/j.ijinfomgt.2019.05.008.

[3] F. Gregorio, G. González, C. Schmidt, and J. Cousseau, "Internet of Things," in Signals and Communication Technology, 2020.

[4] H. Feng, X. Wang, Y. Duan, J. Zhang, and X. Zhang, "Applying blockchain technology to improve agri-food traceability: A review of development methods, benefits and challenges," Journal of Cleaner Production. 2020, doi: 10.1016/j.jclepro.2020.121031.

[5] H. Zhou and W. C. Benton, "Supply chain practice and information sharing," J. Oper. Manag., 2007, doi: 10.1016/j.jom.2007.01.009.

[6] Z. Zahara, Muslimin, S. Hadi, and G. Vesakha, "How to reduce food waste at small restaurant in Indonesia?," Int. J. Recent Technol. Eng., 2019, [Online].

Available: http://www.scopus.com/inward/record.url?eid= 2-s2.0-85070783700\&partnerID=MN8TOARS.

[7] G. C. Stevens and M. Johnson, "Integrating the Supply Chain ... 25 years on," Int. J. Phys. Distrib. Logist. Manag., 2016, doi: 10.1108/IJPDLM-07-2015-0175.

[8] H. Walker and N. Jones, "Supply Chain Management: An International Journal Sustainable supply chain management across the UK private sector Article information," Supply Chain Mnaagement An Int. J., 2012.

[9] K. Jermsittiparsert, S. Wattanapongphasuk, and 
S. Phonwattana, "The impact of supply chain capabilities on the performance of food industry in Thailand," Int. J. Supply Chain Manag., 2019.

[10] J. Kaivo-Oja, P. Virtanen, H. Jalonen, and J. Stenvall, "The effects of the internet of things and big data to organizations and their knowledge management practices," Lect. Notes Bus. Inf. Process., 2015, doi: 10.1007/978-3319-21009-4_38.

[11] A. Paulraj, "Understanding the relationships between internal resources and capabilities, sustainable supply management and organizational sustainability," J. Supply Chain Manag., 2011, doi: 10.1111/j.1745493X.2010.03212.x.

[12] S. E. Fawcett and G. M. Magnan, "The rhetoric and reality of supply chain integration," Int. J. Phys. Distrib. Logist. Manag., 2002, doi: 10.1108/09600030210436222.

[13] H. L. Lee and S. Whang, "Winning the Last Mile of E-Commerce," MIT Sloan Manag. Rev., 2001.

[14] B. B. Flynn, B. Huo, and X. Zhao, "The impact of supply chain integration on performance: A contingency and configuration approach," $J$. Oper. Manag., 2010, doi: 10.1016/j.jom.2009.06.001.

[15] R. Accorsi, M. Bortolini, G. Baruffaldi, F. Pilati, and E. Ferrari, "Internet-of-things Paradigm in Food Supply Chains Control and Management," Procedia Manuf., 2017, doi: 10.1016/j.promfg.2017.07.192.

[16] T. de Vass, H. Shee, and S. Miah, "The effect of 'Internet of Things' on supply chain integration and performance: An organisational capability perspective," Australas. J. Inf. Syst., 2018, doi: 10.3127/ajis.v22i0.1734.

[17] X. Koufteros, M. Vonderembse, and J. Jayaram, "Internal and External Integration for Product Development : The Contingency Ef ...," Integr. Vlsi J., 2005, doi: 10.1111/j.15405915.2005.00067.x.

[18] J. Wilson, "Branding the halal industry," Global Islamic Finance Report (GIFR) 2013. 2013.

[19] K. H. Hanzaee and M. R. Ramezani, "Intention to Halal Products In THe World Markets," Interdiscip. J. Res. Bus., 2011.

[20] M. S. A. Talib and Q. M. H. Sakalayen, "An overlooked aspect of halal supply chains Islamic finance," Int. J. Islam. Mark. Brand., 2020, doi: 10.1504/ijimb.2020.113149.

[21] E. N. Omar and H. S. Jaafar, "Halal supply chain in the food industry - A conceptual model," 2011, doi: 10.1109/ISBEIA.2011.6088842.

[22] K. H. Tan, M. H. Ali, Z. M. Makhbul, and A. Ismail, "The impact of external integration on halal food integrity," Supply Chain Manag., 2017, doi: 10.1108/SCM-05-2016-0171.

[23] F. T. Markham and W. Roy, "Arcs of integration: An international study of supply chain strategies," J. Oper. Manag., 2001.

[24] P. Childerhouse and D. R. Towill, "Arcs of supply chain integration," Int. J. Prod. Res., 2011, doi: 10.1080/00207543.2010.524259.

[25] L. M. Ellram, "The Supplier Selection Decision in Strategic Partnerships," J. Purch. Mater. Manag., $\quad 1990, \quad$ doi: $10.1111 /$ j.1745493x.1990.tb00515.x.

[26] T. P. Stank, S. B. Keller, and P. J. Daugherty, "SUPPLY CHAIN COLLABORATION AND LOGISTICAL SERVICE PERFORMANCE," J. Bus. Logist., 2001, doi: 10.1002/j.21581592.2001.tb00158.x.

[27] J. Maas, "21st century logistics: making supply chain integration a reality," Sloan Manage. Rev., 2000.

[28] S. Saberi, M. Kouhizadeh, J. Sarkis, and L. Shen, "Blockchain technology and its relationships to sustainable supply chain management," Int. J. Prod. Res., 2019, doi: 10.1080/00207543.2018.1533261.

[29] K. J. Petersen, R. B. Handfield, and G. L. Ragatz, "Supplier integration into new product development: Coordinating product, process and supply chain design," J. Oper. Manag., 2005, doi: 10.1016/j.jom.2004.07.009. 